\title{
Characterization of the Insulin-Like Growth Factor Axis in the Human Thymus
}

\author{
O. Kecha, ${ }^{* \dagger}$ H. Martens,$\uparrow$ N. Franchimont, $\uparrow$ I. Achour, $\uparrow$ M.-T. Hazée-Hagelstein, $\uparrow$ C. Charlet-Renard, $\dagger$ V. Geenen $\uparrow$ and \\ R. Winkler* \\ Institute of Pathology CHU-B23, *Laboratory of Molecular Oncology, University of Liège, Liège, Belgium. \\ † Laboratory of Radio-Immunology, University of Liège, Liège, Belgium.
}

Key words: insulin-like growth factors, insulin-like growth factor binding, proteins, thymus, T lymphocytes.

\begin{abstract}
The components of the insulin-like growth factor (IGF) axis have been investigated in the normal human thymus. Using ribonuclease protection assays (RPA), IGF-II transcripts were detected in the normal human thymus. By reverse transcriptase polymerase chain reaction (RT-PCR) analyses, promoters $\mathrm{P} 3$ and $\mathrm{P} 4$ were found to be active in the transcription of IGF2 gene within human thymic epithelial cells (TEC). No IGF-II mRNA could be detected in human lymphoid Jurkat T cells with 30 cycles of RT-PCR. By Northern blot analyses, IGFBP-2 to -6 (but not IGFBP-1) were found to be expressed in TEC with a predominance of IGFBP-4. Interestingly, Jurkat T cells only express IGFBP-2 but at high levels. The type 1 IGF receptor was detected in Jurkat T cells but not in human TEC. The identification of the components of the IGF axis within separate compartments of the human thymus adds further evidence for a role of this axis in the control of T-cell development. The precise influence of thymic IGF axis upon T-cell differentiation and immunological self-tolerance however needs to be further investigated.
\end{abstract}

The thymus is the primary lymphoid organ involved in the development of competent and self-tolerant $\mathrm{T}$ lymphocytes (1). The induction of thymic central T-cell self-tolerance is thought to be the consequence of $\mathrm{T}$-cell apoptosis or the developmental arrest of immature $T$ cells bearing a randomly rearranged receptor for self-antigens presented in the thymic microenvironment (2-6). We showed in our previous studies that thymic epithelial and nurse cells (TEC/TNC) from different species express neuroendocrine-related polypeptide precursors/genes belonging to neurohypophysial, tachykinin and neurotensin families (7-9). Thymic neuroendocrinerelated precursors have been proposed to recapitulate at the molecular level the dual role of the thymus in T-cell development and self-tolerance (10-12). Regarding the insulin family, previous studies have reported a predominant expression of insulin-like growth factor-II (IGF-II) over IGF-I in human foetal organs including the thymus $(13,14)$. By immunocytochemistry (ICC), we have reported that IGF-II is the dominant peptide of the insulin family synthesized by TEC from human and rat thymus (15). Immunoreactive (IR)
IGF-I was also detected in the thymus, but IGF-I distribution was restricted to macrophage-like thymic stromal cells (15). IGF-I mRNA and protein have also been identified in murine macrophage cell lines from thymic and non-thymic origin (16). IR proinsulin could not be identified by ICC in the human thymus.

IGF-II is a 67 amino acid peptide which is thought to be a growth regulator during foetal development $(17,18)$. The human IGF2 gene is located on the chromosome 11p15 (19). It contains nine exons and four promoters (20), the activities of which are regulated in a tissue- and developmental-specific manner. Such specificity gives rise to multiple IGF-II transcripts with different 5'- and 3'-non-coding regions (21). The $\mathrm{P} 1$ promoter is only active in adult human liver and it yields a $5.3 \mathrm{~Kb}$ mRNA. P2, P3 and $\mathrm{P} 4$ promoters are active in foetal liver as well as in adult non-hepatic tissues where they activate the production of 5,6 and $4.8 \mathrm{~Kb}$ transcripts, respectively (22).

Currently, there is no information concerning the active promoter of IGF2 in thymic cells. In the first part of this

Correspondence to: Ouafae Kecha, Institute of Pathology CHU-B23, Molecular Oncology and Neuroendocrine-Immunology, University of Liège, B-4000 Liège 1-Sart Tilman, Belgium, (e-mail: s903012@student.ulg.ac.be).

(C) 1999 Blackwell Science Ltd 
study we analyse IGF2 gene expression in the thymus and identify the thymic active promoters by RNase protection assay and RT-PCR respectively.

IGF activity is not only dependent on the regulation of their synthesis but also on the presence of IGF receptors on target cells: type 1 (IGF-1R) (23), type 2/mannose6-phosphate (IGF-2R) (24) IGF-receptors and insulin receptors (25), as well as on the presence of IGF-binding proteins (IGFBPs) (26). These IGFBPs are found in many body fluids and in the conditioned media of a wide variety of cell types (27) where they are presumed to regulate IGF bioavailability and bioactivity for their receptors (28). Type 1 and type 2 IGF receptors are expressed by freshly isolated immature and mature T lymphocytes $(29,30)$, as well as by human leukemic lymphoblasts (31), indicating that thymic IGFs could play a role in T-cell development. Little is known about IGFBP expression in cells from thymic origin.

In the second part of this work, we investigated the expression of IGF receptors and IGFBPs in the human TEC, and in the human Jurkat T-lymphoblast cell line (32). Given the high heterogeneity of thymic cells, the human Jurkat T-lymphoblast cell line (31) was used to evaluate the components of the IGF axis expressed in the lymphoid compartment.

\section{Materials and methods}

\section{Human tissue samples}

Thymic fragments were obtained from children (aged from 6 months to 3 years) undergoing corrective cardiovascular surgery for congenital cardiopathies. Human liver and placenta samples were used as positive controls. Tissue samples were frozen in liquid nitrogen and stored at $-70^{\circ} \mathrm{C}$. This study was approved by the ethical committee of the University Hospital of Liège.

\section{TEC cultures}

TEC cultures were obtained from thymic explants as described by Martens et al. (33). Briefly, surgical thymic fragments were cut and washed twice by sedimentation for $5 \mathrm{~min}$ in HBSS (ICN, Costa Mesa, CA, USA). The small fragments $(<2 \mathrm{~mm})$ were cultured in Eagle's minimum essential medium containing D-valine (Life Technology, Gaithersburg, MD, USA) in order to reduce fibroblast growth, supplemented with $2 \mathrm{mM}$ L-glutamine, $10 \mathrm{mM}$ HEPES, $100 \mathrm{U} / \mathrm{m}$; penicillin, $100 \mu \mathrm{g} / \mathrm{ml}$ streptomycin and $10 \%$ heatinactivated foetal calf serum (Life Technology). Fragments were allowed to adhere to T-75 flasks in the same medium in a humidified atmosphere at $37^{\circ} \mathrm{C}$ and $5 \% \mathrm{CO}_{2}$. On day 17 , explants and confluent cells were trypsinized (Trypsin Versene, BioWhittaker, Walkersville, MD, USA) and filtered through nylon gaze to eliminate fragment residues. TEC were subcultured for 1 week before RNA extraction. Purity of human TEC cultures was around $75-85 \%$ as determined by Martens et al. (33).

\section{Jurkat T-cell line cultures}

The human Jurkat T lymphoblast cell line (32) was cultured in RPMI 1640 (BioWhittaker) containing $2 \mathrm{mM}$ l-glutamine, $1 \%$ sodium pyruvate, $1 \%$ nonessential amino acids, $100 \mathrm{U} / \mathrm{ml}$ penicillin, $100 \mu \mathrm{g} / \mathrm{ml}$ streptomycin and $10 \%$ heat-inactivated FCS (Life Technology) in a humidified atmosphere at $37^{\circ} \mathrm{C}$ and $5 \% \mathrm{CO}_{2}$.

\section{RNA isolation}

Total RNA was extracted from tissue samples and cells using RNAzol ${ }^{\mathrm{TM}} \mathrm{B}$ (Biotex Laboratories Inc. Houston, TX, USA) according to the manufacture instructions. The amount of total RNA was quantified by UV spectrophotometry and RNA integrity was analysed by agarose gel electrophoresis after ethidium bromide staining.

\section{Ribonuclease protection assay}

Ribonuclease protection assay (RPA) was performed as described by Lambert et al. (34). Briefly, 10,20 and $30 \mathrm{mg}$ or $20,40,60 \mathrm{mg}$ of total RNA were hybridized for $16 \mathrm{~h}$ at $50^{\circ} \mathrm{C}$ with $10^{5}$ c.p.m. of a $\left(\alpha-{ }^{32} \mathrm{P}-\mathrm{CTP}\right)$-labelled IGF-II or IGF-I RNA probes, respectively $(33,34)$. The riboprobes were synthesized from the 800-bp IGF-II-pSPT18 Sst II linearized plasmid, or 600-bp IGF-IpSPT18 Sma I using 5-10 units of the SP6 RNA polymerase from the Promega transcription kit (Promega Corp.). The riboprobes are 440- and 660-nt in length containing 20-nt of poly-linker sequence. Hybridization and RNase treatment were performed as described by Lambert et al. (33), and the samples were submitted to electrophoresis on a $4 \%$ polyacrylamide sequencing gel containing $8 \mathrm{M}$ urea and dried gel were exposed to X-ray film for $48 \mathrm{~h}$.

Reverse transcription polymerase chain reaction

IGF-II mRNA levels were analysed by RT-PCR. Five mg of total RNA were reverse-transcribed in the presence of 10 pmole of antisense primer: primer 9 (Table 1 ) at $48{ }^{\circ} \mathrm{C}$ for 60 min with 200 units Superscript II reverse transcriptase (Life Technologies), 1X first strand buffer, $10 \mathrm{mM}$ dithiothreitol, $0.5 \mathrm{mM}$ of each deoxynucleotide triphosphate. The reaction was stopped by incubation at $90{ }^{\circ} \mathrm{C}$ for $5 \mathrm{~min}$ and samples were quick-chilled on ice.

Five $\mu 1$ of newly transcribed cDNA was amplified by PCR for 25-30 cycles at $95^{\circ} \mathrm{C} / 1 \mathrm{~min}, 51^{\circ} \mathrm{C} / 1 \mathrm{~min} 30 \mathrm{~s}$ and $72^{\circ} \mathrm{C} / 2 \mathrm{~min}$ followed by $5 \mathrm{~min}$ incubation at $72{ }^{\circ} \mathrm{C}$, in the presence of $1 \mathrm{X}$ Taq buffer, $200 \mu \mathrm{M}$ dNTP mix, $1 \mu \mathrm{M}$ of the sense primer: primer-5, primer-6, or primer-7 and primer-9 as antisense primer (35) (Primers are from Pharmacia LKB Biotechnology, Piscataway, NJ, USA).The PCR products were fractioned by electrophoresis on $0.8 \%$ agarose gel.

\section{Southern blotting and hybridization}

The RT-PCR products were submitted to gel agarose electrophoresis and vacuum blotted in $10 \mathrm{X}$ SSC $(20 \times \mathrm{SSC}$ : $3 \mathrm{M} \mathrm{NaCl}, 0.3 \mathrm{M}$ Sodium Citrate Dihydrate) for $90 \mathrm{~min}$ onto Zeta-Probe GT nylon membrane (Bio-Rad, Hercules, CA, USA). The 800-bp Pst I fragment of the human IGF-II cDNA probe (33) was labelled with $\left[\alpha_{-}{ }^{32} \mathrm{P}\right] \mathrm{dCTP}(50 \mathrm{mCi}$ at a specific activity of $3000 \mathrm{Ci} / \mathrm{mmol}$; ICN) by random priming using Ready To Go reaction mix (Pharmacia LKB). Unincorporated nucleotides were removed by gel filtration on a Sephadex G50 column and the blotted membranes were hybridized for $16 \mathrm{~h}$ at $42^{\circ} \mathrm{C}$ to $5.10^{7}$ c.p.m. of the probe. The washes were performed at $65^{\circ} \mathrm{C}$ as follows: twice in $40 \mathrm{mM} \mathrm{Na}{ }_{2} \mathrm{HPO}_{4}(\mathrm{pH} \mathrm{7.2}), 5 \%$ SDS for $30 \mathrm{~min}$ and twice in $40 \mathrm{mM} \mathrm{Na}{ }_{2} \mathrm{HPO}_{4}(\mathrm{pH} 7.2), 1 \%$ SDS for $30 \mathrm{~min}$. The blots were exposed for $1 \mathrm{~h}$ to phosphorimager.

\section{Northern blotting and hybridization}

Total RNA were prepared from tissue samples and cell cultures as described above. Fifteen to $20 \mathrm{mg}$ of TEC and Jurkat T cell line RNA and $5 \mathrm{mg}$ of liver or placenta RNA were loaded on a formaldehyde agarose gel following denaturationon. The gel was stained with ethidium bromide to visualize RNA standards and ribosomal RNA (rRNA) and total RNA were blotted onto Gene Screen Nylon membran (Dupont, NEN Research Product, Boston, USA). Hybridization were carried out at $42{ }^{\circ} \mathrm{C}$ for $16 \mathrm{~h}$ according to the manufacturer's instructions in $10 \mathrm{ml}$ hybridization mixture containing $5.10^{7}$ c.p.m. of ${ }^{32} \mathrm{P}$ randomly primed probe (as described previously) and posthybridization washes were performed as follows: twice in $2 \times$ SSPE $(20 \times$ SSPE: $3 \mathrm{M}$ $\mathrm{NaCl}, 0.02 \mathrm{M}$ EDTA and $0.2 \mathrm{M} \mathrm{NaH} \mathrm{PO}_{4} \mathrm{H}_{2} \mathrm{O}$ ) at room temperature for $15 \mathrm{~min}$, twice in $2 \times \mathrm{SSPE}, 2 \% \mathrm{SDS}$ at $65^{\circ} \mathrm{C}$ for $45 \mathrm{~min}$, and finally twice in $0.1 \times$ SSPE at room temperature for $15 \mathrm{~min}$. Hybridized membranes were exposed to X-Ray film. The blots were stripped and rehybridized (in the same condition) with $\alpha-{ }^{32} \mathrm{P}$-labelled $\beta$-actin probe (kindly provided by Dr Bell, GI) to assess RNA loading. Relative hybridization levels were determined by densitometric analysis. In all cases, IGFBP levels were normalised with respect to the level of $\beta$-actin expression and to the length of the probes. The following probes were used for hybridization: IGF-IR probe was obtained from ATCC (Rockville, MD, USA), IGFBP-1 and-2 are from JCR Biopharmeuticals, Inc. (San Diego, CA, USA) and IGFBP-3, -4, -5 and-6 probes were purchased from Chiron Cell Corporation (Emeryville, CA, USA).

\section{Results}

\section{IGF-II $m R N A$ expression and identification of IGF2 active promotors in the thymus}

IGF2 gene expression in the human thymus was analysed by RPA. A ${ }^{32}$ P-labelled IGF-II RNA probe (36) was hybridized with increasing amounts of total RNA from the human thymus and term placenta used as a positive control (Fig. 1). 


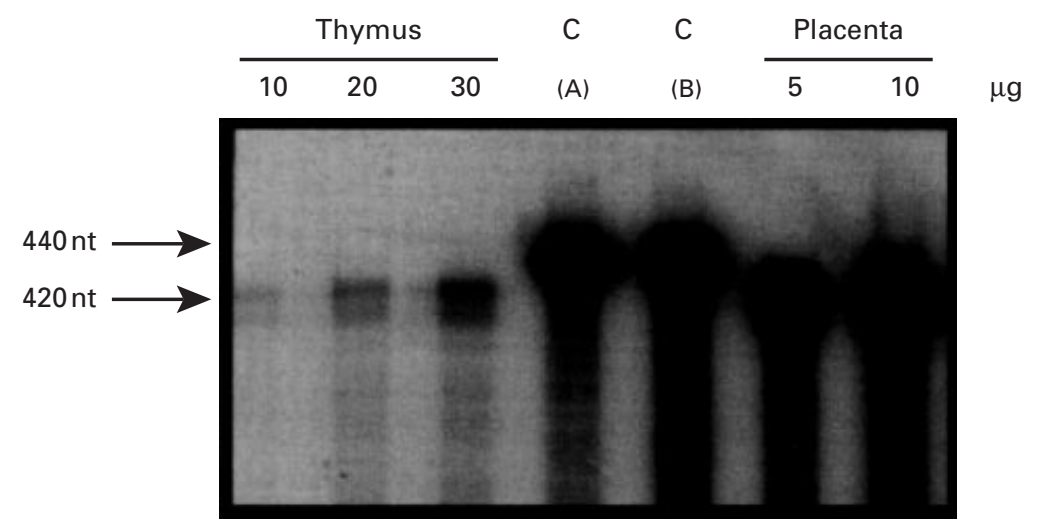

FIG. 1. Identification of IGF-II transcripts in human thymus by ribonuclease protection assay (RPA). Ten, 20 and $30 \mu \mathrm{g}$ of total human thymus RNA and 5 and $10 \mu \mathrm{g}$ of total human placenta RNA were hybridized with a $\left(\alpha{ }_{-}^{32} \mathrm{P}-\mathrm{CTP}\right)$ labelled antisense IGF-II riboprobe ( $10^{5} \mathrm{c} . \mathrm{p} \cdot \mathrm{m}$.); $\mathrm{C}_{\mathrm{A}}$ : Probe alone; $\mathrm{C}_{\mathrm{B}}: 10^{5}$ c.p.m. probe incubated with $30 \mathrm{mg}$ of yeast RNA and not subjected to RNase treatment as described in Materials and Methods; nt: nucleotides (exposure time is $48 \mathrm{~h}$ at $-70^{\circ} \mathrm{C}$ ).

The IGF-II message was already detected using 5 or $10 \mu \mathrm{g}$ of total placenta or thymic RNA, respectively, and its level increased with increasing amount of RNA. The size of the protected fragments were 20-nt shorter than the unhybridized probe (440-nt), due to the digestion of the linker sequences transcribed from the pSPT18 vector. Two protected IGF-II fragments were detected. This result indicates that $I G F 2$ is indeed expressed in the thymus, but does not provide information concerning the cellular origin of the transcripts nor the identity of the active promoters. We could not detect any IGF-I mRNA in the human thymus using RPA (data not shown). These experiments were realized with three different thymuses and gave similar results.

We also studied IGF-II mRNA expression in the Jurkat cells by RT-PCR. No amplification was observed after 30 cycles indicating that the expression level was probably below the detection level of this very sensitive technique (data not shown).

To identify promoters responsibles of IGF-II mRNA expression in cultured human TEC, RT-PCR analyses were performed using a common 3'-primer derived from exon 9 and a 5 -primer from exon 5 or 6 , whose expression is under the control of promoters $\mathrm{P} 3$ and $\mathrm{P} 4$, respectively. The RT-PCR products specific for promoters P3 (662 bp, Fig. 2A, lane 1) and P4 (596 bp, Fig. 2A, lane 2) were detected in TEC RNA. RT-PCR with primers from exon 9 and 7 amplified a $450 \mathrm{bp}$ PCR product which correspond to the common coding sequence for all IGF-II transcripts (Fig. 2A, lane 3 ). This experiment was realized three times and similar results were obtained. The identity of the amplified cDNAs was controlled by Southern blot hybridization to a $800 \mathrm{bp}$ human IGF-II cDNA probe containing exons 7,8 and a portion of exon 9 (32) (Fig. 2B). Thus, promoters P3 and P4 are active in TEC.

\section{IGFBPs and type 1 IGF receptor $m R N A$ expression in TEC and Jurkat T cells}

Northern blot analyses were used to study the level of IGFBPs transcripts in the primary cultures of human TEC and in the lymphoid Jurkat T-cell line. Human liver RNA was used as a control tissue (Fig. 3). IGFBP-3 (Fig. 3C), IGFBP-4 (Fig. 3C), IGFBP-5 (Fig. 3D) and IGFBP-6 (Fig. 3E) transcripts were detected both in TEC and liver, but not in Jurkat T cells. By contrast, IGFBP-2 mRNA was abundant in the Jurkat T cells, and barely detectable in the TEC (Fig. 3A). IGFBP-1 mRNA was not detected neither in TEC, nor in Jurkat $T$ cells (data not shown). The signals were quantified by densitometric analysis after rehybridization with $\beta$-actin probe. IGFBP mRNA levels were expressed as the percentage of $\beta$-actin with respect to the probe length and compared to IGFBP expression in the liver. IGFBP-4 mRNA was the dominant IGFBP in TEC and was 14-, 21-, and 20-fold more abundant than BP-3, BP-5, and BP-6 respectively (in arbitrary units).

Using Northern blot analysis, type 1 IGF receptor (IGF-1R) mRNA (11 kb) was only found in Jurkat T cells (Fig. 3F). Human placenta was used as a positive control tissue. These experiments were repeated and realized with different total RNA extracts.

\section{Discussion}

In the present study, we confirmed the expression of different members of the IGF axis (IGF-I, IGF-II, IGF-1R and IGFBPs) in the human thymus, in TEC primary cultures and in Jurkat, a human lymphoid T-cell line. Interestingly, our results show that the thymic epithelial and lymphoid compartments exhibit different patterns of expression for members of the IGF axis:

1. TEC express IGF-II under the control of P3 and P4, most of the IGFBPs (BP-2 to-6), but no IGF-1R mRNAs.

2. Jurkat $T$ cells do not express IGF-II, express only IGFBP-2 and are rich in IGF-1R transcripts.

The identification of IGF-II mRNA in TEC indicates that IR IGF-II previously detected in the epithelial compartment of human thymuses excised from 6-month-old to 3-year-old children (15) is probably synthesized by these cells. Other autors have localised IGF-II mRNA and peptide, by in-situ hybridization and ICC, in the mesenchymal cells and imma- 


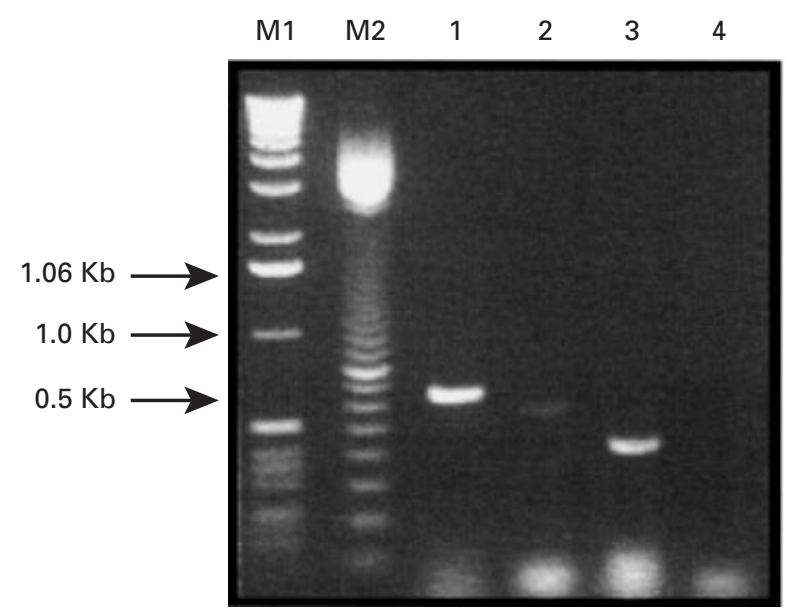

(B)

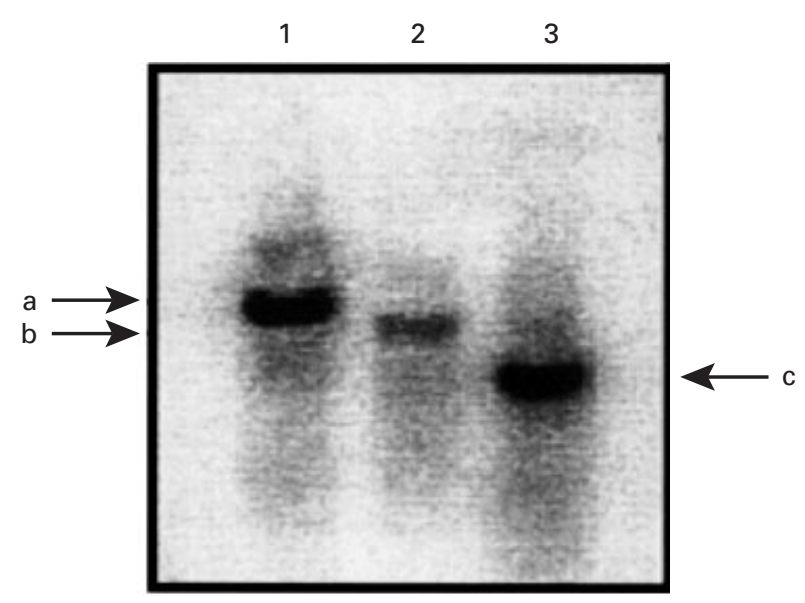

FIG. 2. (A) Identification of the promoters responsibles of IGF-II mRNA expression in human TEC. Amplification of mRNA from human TEC primary culture by RT-PCR. The RT-PCR products were separated through agarose gel electrophoresis and visualized with ethidium bromide. The predicted sizes for the amplification bands using primer specific for exon 5, exon 6 or exon 7 as upstream primer with primer specific for exon 9 as downstream primer were $660 \mathrm{bp}$ (lane 1), $596 \mathrm{bp}$ (lane 2) and $450 \mathrm{bp}$ (lane 3 ), $\mathbf{M}_{1}=1 \mathrm{~kb}$ ladder, $\mathbf{M}_{2}=100 \mathrm{bp}$ markers, lane $4=$ negative control (no RNA). (B) Southern blot hybridization of TEC RT/PCR products(a: $660 \mathrm{bp}$, b: $596 \mathrm{bp}$, c: $450 \mathrm{bp}$ ) to the $800 \mathrm{bp}$ human IGF-II cDNA probe.

ture hematopoietic precusors of foetal human thymus (13, 14, 37). The difference between those results and our observations could be due to the difference in the developmental stages of the analysed tissues. In transgenic mice overexpressing IGF-II, in-situ hybridization revealed the high expression of the IGF-II transgene within non-lymphocyte cells of the thymic medulla $(38,39)$.

Two IGF-II mRNA protected fragments were detected by RPA in the thymus. The shorter transcript may correspond to an IGF-II mRNA variant in the region detected by the probe used in the assay $(40,41)$.

The expression of the IGF-II gene in TEC is under the control of promoters $\mathrm{P} 3$ and $\mathrm{P} 4$ which are known to be active in all foetal tissues, as well as in the extra-hepatic adult tissues (21). To the best of our knowledge, the identity of IGF-II gene promoters in TEC has not been addressed before.

IGF-I could not be detected in TEC by RPA. The absence of IGF-I transcripts is in accordance with our previous observations according which IR IGF-I was restricted to thymic macrophages (15). In accordance with our own observations, Arkins et al. have shown that a variety of murine macrophage cells and cell lines express the IGF-I mRNA, while this transcript was undetectable in the whole thymus (16).

Timsit and coworkers have reported that primary cultures of TEC respond to IGF-I, an effect which could be blocked by an anti-IGF-I receptor antibody (42). The apparent discrepancy with the absence of IGF-1R mRNA in our study could be due to some differences in the conditions of TEC primary cultures, the presence of insulin receptor or in the regulation of expression of the $I G F-1 R$ gene.

TEC express different levels of IGFBP-2 to-6, with a predominance of IGFBP-4. IGFBP-4 is thought to be an inhibitor of IGF biological activity (43). However, recent results concerning IGFBP-4 knock-out mice, presented by
Pintar et al. at the Fourth International Symposium on IGFs (44) have raised the possibility of a misinterpretation of this inhibitory effect. This IGFBP has also been detected in murine thymic macrophages and in macrophage cell lines (45). As suggested by these authors, macrophage-derived IGFBP-4 might antagonize the extracellular effects of IGF-I.

Similar experiments were performed with the lymphoid Jurkat T-cell line (32). This cell line was used as a global representative of the lymphoid compartment in the thymus. By contrast with the subpopulations of thymic T cells (thymocytes), the Jurkat T-cell line offers the advantage of an homogenous population which can be reproducibly analysed, the disadvantage being that it is a cancer cell line so that all informations have to be interpreted with caution. No IGF-II mRNA could be detected in Jurkat $\mathrm{T}$ cells by RT-PCR analysis, while these cells were found to express both IGF-1R mRNA, and IGFBP-2 trancripts. The presence of functional IGF-1R (46) and IGF-2R (47) on Jurkat cells has been described before. These receptors have been reported to be expressed by freshly isolated immature and mature $\mathrm{T}$ lymphocytes $(29,30)$, as well as by human leukemic lymphoblasts (32).

In summary this study confirms - at the molecular levelthe existence of IGF axis members in the human thymus with a predominance of IGF-II synthesis within TEC and the expression of IGF receptors by lymphoid cells. The characterization of a complete IGF system in a lymphopoietic site adds another argument for its implication in thymic T-cell differentiation and self-tolerance (48). IGF-II transgenic mice overexpress IGF-II mRNA in the thymus and spleen, and their thymus shows a significant hyperplasia (35). In addition, the same group showed that overexpression of IGF-II increases thymic cellularity and stimulates the generation of phenotypically normal $\mathrm{T}$ cells with a preference to $\mathrm{CD} 4^{+}$ cells (38). The precise involvment of the IGF axis in T-cell 
(A)

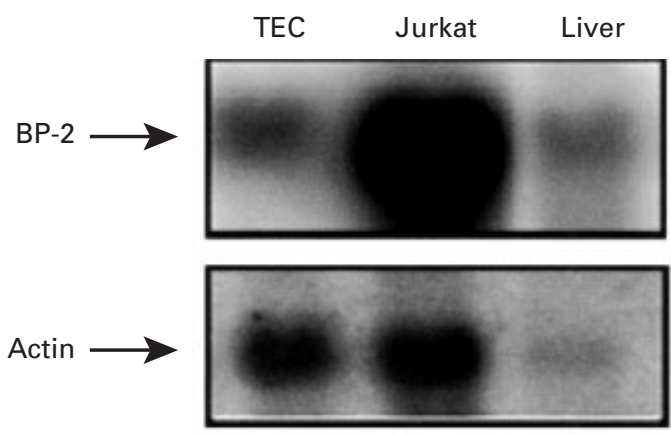

(C)
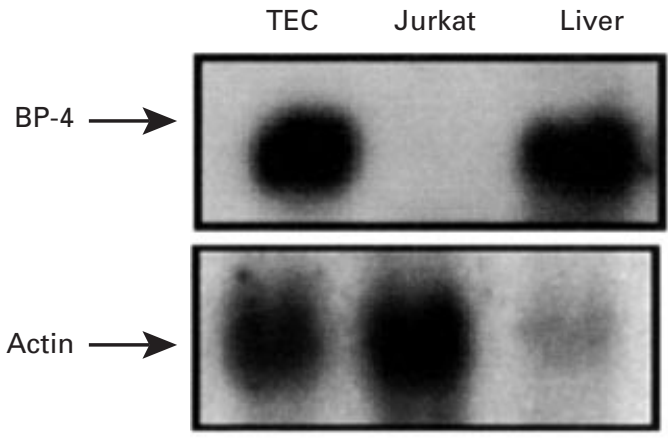

(E)
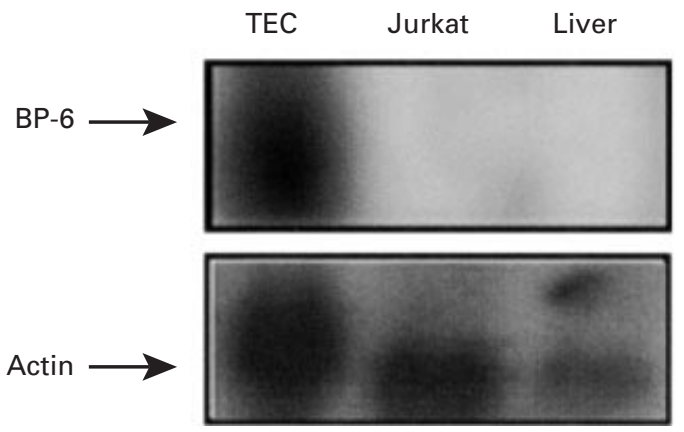

(B)

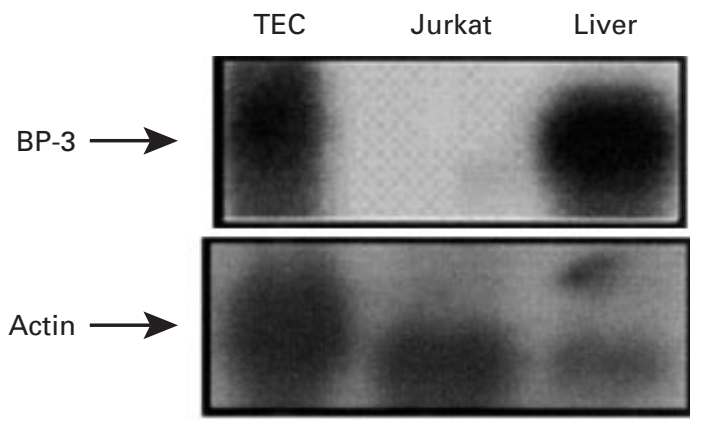

(D)
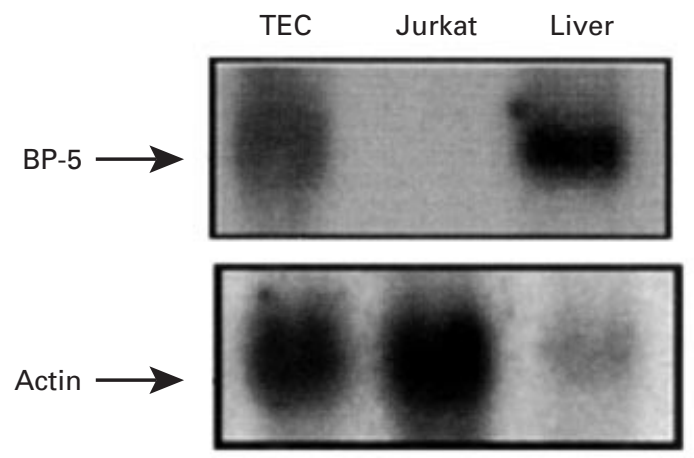

(F)

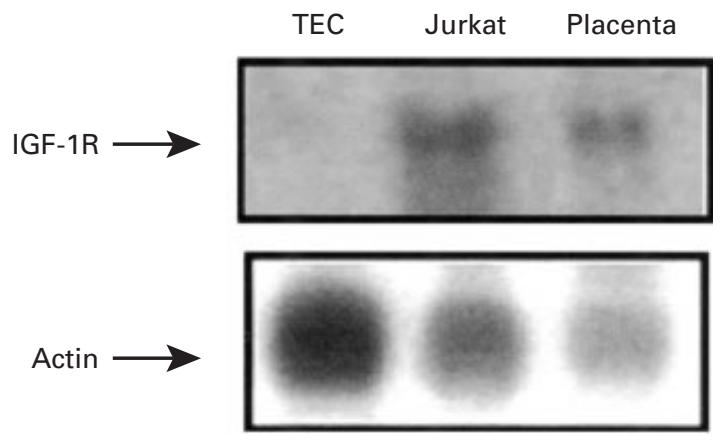

FIG. 3. Northern blot analyses of IGFBPs and IGF-1R mRNAs in human TEC primary cultures, Jurkat T-cell line and human liver or placenta as positive controls. Twenty $\mu \mathrm{g}$ of total cellular RNA from TEC and Jurkat, and $5 \mu \mathrm{g}$ of total RNA from liver or placenta were hybridized with human IGFBP-2 to-6 and IGF-1R cDNAs probe. The exposure time was $48 \mathrm{~h}$ at $-70{ }^{\circ} \mathrm{C}$ with amplifying screens (IGFBP-2,-3,-4,-6) and 1 week for IGFBP-5. (A-E) (Top) Autoradiographies of Northern blots analysis of IGFBP-2,-3 -4, -5 and -6 (respectively) in TEC, Jurkat T-cell line, and liver. (F) (Top) Autoradiography of Northern blots analysis of type-1 IGF receptor in TEC, Jurkat T-cell line, and placenta. The exposure time was $48 \mathrm{~h}$ at $-70^{\circ} \mathrm{C}$. (A-F) (Bottom) Blots were stripped and hybridized with labelled $\beta$-actin cDNA probe.

differentiation is under current investigation in our laboratory through the use of murine foetal thymus organ cultures.

\section{Accepted 7 January 1999}

\section{References}

1 Herold KC, Quintans J. Immunological mechanisms causing autoimmune endocrine diseases. In: DeGroot LJ, Bessen M, Burger HG, Jamison LJ, Lorianx DL, Marshall JC, Odell WD, Potts Jr JT, Rubenstein AH, Cahill GF, Martini L, Nelson DH, eds. Endocrinology, 3rd edn. Philadelphia: Saunders, 1995; 2990-3012.
2 Lo D, Ron Y, Sprent J. Induction of MHC-restricted specificity and tolerance in the thymus. Immunol Res 1986; 5: 221-232.

3 Fowlkes BJ, Pardoll DM. Molecular and cellular events of T-cell development. Adv Immunol 1989; 44: 207-264.

4 Kappler JW, Roehm N, Marrack P. T-cell tolerance by clonal elimination in the thymus. Cell 1987; 49: 273-280.

5 Von Boehmer H, Kisielow P. Self-nonself discrimination by $\mathrm{T}$ cells. Science 1990; 248: 1369-1372.

6 Nossal GJV. Negative selection of lymphocytes. Cell 1994; 76: 229-239.

7 Geenen V, Legros JJ, Franchimont P, Baudrihaye M, Defresne MP, Boniver J. The neuroendocrine thymus: coexistence of oxytocin and neurophysin in the human thymus. Science 1986; 232: 508-511.

8 Ericsson A, Geenen V, Robert F, Legros JJ, Vrindts-Gevaert Y, Franchimont P, Brene S, Persson H. Expression of preprotachykinin A 
and neuropeptide $\mathrm{Y}$ messenger RNA in the thymus. Mol Endocrinol 1990; 4: 1211-1219.

9 Vanneste Y, Ntodou Thome A, Vandersmissen E, Charlet C, Franchimont D, Martens H, Lhiaubet A, Schimpff RM, Rostène W, Geenen V. Identification of neurotensin-related peptides in human thymic epithelial cell membranes and relationship with major histocompatibility complex class I molecules. J Neuroimmunol 1997; 76: 161-166.

10 Geenen V, Robert F, Martens H, De Groote D, Franchimont P. The thymic education of developing $\mathrm{T}$ cells in self neuroendocrine principles. J Endocrinol Invest 1992; 15: 621-629.

11 Martens H, Goxe B, Geenen V. The thymic repertoire of neuroendocrine self-antigens: physiological implications in T-cell life and death. Immunol Today 1996; 17: 312-317.

12 Geenen V, Kecha O, Martens H. Thymic expression of neuroendocrine self-peptide precursors: role in $\mathrm{T}$ cell survival and self-tolerance. J Neuroendocrinol 1998; 10: 811-822.

13 Han VKM, D'Ercole AJ, Lund PK. Cellular localization of somatomedin (insulin-like growth factor) messenger RNA in the human fetus. Science 1987; 239: 193-196.

14 Han VKM, Lund PK, Lee DC, D'Ercole AJ. Expression of somatomedin/ insulin-like growth factor messenger ribonucleic acids in the human fetus: identification, characterization, and tissue distribution. J Clin Endocrinol Metab 1988; 66: 423-429.

15 Geenen V, Achour I, Robert F, Vandersmissen E, Sodoyez JC, Defresne MP, Boniver J, Lefèbvre PJ, Franchimont P. Evidence that insulin-like growth factor II (IGF-II) is the dominant thymic peptide of the insulin superfamily. Thymus 1993; 21: 115-127.

16 Arkins S, Rebeiz N, Biragyn A, Reese DL, Kelley KW. Murine macrophages express abundant insulin-like growth factor-I class I Ea and $\mathrm{Eb}$ transcripts. Endocrinology 1993; 133: 2334-2343.

17 De Chiara TM, Efstratiadis A, Robertson EJ. A growth-deficiency phenotype in heterozygous mice carrying an insulin-like growth factor II gene disrupted by targeting. Nature 1990; 345: 78-80.

18 Humbel RE. Insulin-like growth factors I and II. Eur J Biochem 1990; 190: $445-462$.

19 Brissenden JE, Ullrich A, Francke U. Human chromosomal mapping of genes for insulin-like growth factors I and II and epidermal growth factor. Nature 1984; 310: 781-785

20 Holthuizen P, LeRoith D, Lund PK, Roberts Jr CT, Rotwein P, Spencer EM, Sussenbach JS. Revised nomenclature for the insulin-like growth factors genes and transcripts. In: Spencer EM, ed. Modern Concepts of Insulin-like Growth Factors. New York: Elsevier Science, 1991: 733-736.

21 De Pagter-Holthuizen P, Jansen M, Van Schark FMA, Van der Kammen RA, Oosterwijk C, Van den Brande JL, Sussenbach JS. Differential expression of the human insulin-like growth factor II gene: characterization of the IGF-II mRNAs and mRNA encoding a putative IGF-II associated protein. Biochem Biophys Acta 1988; 950: 282-295.

22 De Pagter-Holthuizen P, Jansen M, Van Schaik FMA, Van der Kammen RA, Sussenbach JS. The human insulin-like growth factor II contains two development-specific promoters. FEBS Lett 1987; 214: 259-264.

23 Le Roith D, Werner H, Beitner-Johnson D, Roberts CTJ. Molecular and cellular aspects of the insulin-like growth factor I receptor. Endocr Rev 1995; 16: 143-163.

24 Morgan DO, Edman JC, Standring DN, Fried VA, Smith MC, Roth RA, Rutter WJ. Insulin-like growth factor II receptor as a multifunctional binding protein. Nature 1987; 329: 301-307.

25 Morrione A, Valentinis B, Xu SQ, Yumet G, Louvi A, Estrafiadis A, Baserga R. Insulin-like growth factor II stimulates cell proliferation through the insulin receptor. Proc Natl Acad Sci USA 1997; 99: 3777-3782.

26 Shimasaki S, Ling N. Identification and molecular chracterisation of insulin-like growth factor binding proteins (IGFBP-1, -2, -3, -4, -5 and -6). Prog Growth Factor Res 1991; 3: 243-266.

27 Jones J, Clemmons DR. Insulin-like growth factors and their binding proteins: biological actions. Endocr Rev 1995; 16: 3-34.

28 Kelly KM, Oh Y, Gargosky SE, Gucev Z, Matsumoto T, Hwa V, Lilly NG, Simpson DM, Rosenfeld RG. Insulin-like growth factor-binding proteins (IGFBPs) and their regulatory dynamics. Int J Biochem Cell Biol 1996; 28: 619-637.
29 Kozak RW, Haskell JF, Greenstein LA, Rechler MM, Waldmann TA, Nissley SP. Type I and II insulin-like growth factor receptors on human phytohemagglutinin-activated T lymphocytes. Cell Immunol 1987; 109: 318-331.

30 Kooijman R, Scholtens LE, Rijkers GT, Zegers BJM. Type 1 insulinlike growth factor receptor expression in different developmental stages of human thymocytes. $J$ Endocrinol 1995; 147: 203-209.

31 Lee PD, Rosenfeld RG, Hintz RL, Smith SD. Characterization of insulin, insulin-like growth factor I and II, and growth hormone receptors on human leukemic lymphoblasts. J Clin Endocrinol Metab 1986; 62: 28-35.

32 Weiss A, Wiskocil RL, Stob JD. The role of T3 surface molecules in the activation of human T cells: a two stimulus requirement for IL-2 production reflects events occuring at a pre-translational level. J Immunol 1984; 133: $123-128$.

33 Martens H, Malgrange B, Robert F, Charlet C, De Groote D, Heyman D, Godard A, Soulillou JP, Moonen G, Geenen V. Cytokine production by human thymic epithelial cells: control by the immune recognition of the neurohypophysial self-antigen. Regul Pept 1996; 67: 39-45.

34 Lambert S, Vivario J, Boniver J, Gol-Winkler R. Abnormal expression and structural modification of the insulin-like growth-factor II gene in human colorectal tumors. Int $J$ Cancer 1990; 46: 405-410.

35 Van Buul-Offers SC, De Haan K, Reijnen-Gresnigt MG, Meinsma D, Jansen M, Oei SL, Bonte EJ, Sussenbach JS, Van Den Brand JL. Overexpression of human insulin-like growth factor-II in transgenic mice causes increased growth of the thymus. J Endocrinol 1995; 144: 491-502.

36 Bell GI, Merryweather JP, Sanchez-Pescator R, Stempien MM, Priestly L, Scott J, Rall LB. Sequence of a cDNA clone encoding human preproinsulin-like growth factor II. Nature 1984; 31: 775-777.

37 Han VKM, Hill DJ, Strain AJ, Towle AC, Lauder JM, Underwood LE, D'Ercole AJ. Identification of somatomedin/insulin-like growth factor immunoreactive cells in the human fetus. Pediatric Res 1987; 22: 245-249.

38 Kooijman R, Van Buul-Offers SC, Scholtens LE, Schuurman HJ, Van den Brande LJ, Zegers BJM. T cell development in insulin-like growth factor II transgenic mice. J Immunol 1995; 5732-5747.

39 Van der Ven LTM, Roholl PJM, Reijnen-Gresnigt MG, Bloemen RJ, van Buul-Offers SC. Expression of insulin-like growth factor II (IGF-II) and histological changes in the thymus and spleen of transgenic mice overexpressing IGF-II. Histochem Cell Biol 1997; 107: 193-203.

40 Jansen M, Van Schaik FMA, Van Tol H, Van den Brande JL, Sussenbach JS. Nucleotide sequences of cDNA encoding precursors of human insulinlike growth factor II (IGF-II) and an IGF-II variant. FEBS Lett 1985; 179: $243-246$.

41 Yeh J, Danehey FT, Osathanodh R, Villa-Komaroff L. mRNAs for insulin-like growth factor-II (IGF-II) and variant IGF-II are co-expressed in human fetal ovary and uterus. Mol Cell Endocrinol 1991; 80: $75-82$.

42 Timsit J, Savino W, Safieh B, Chanson P, Gagnerault MC, Bach JF, Dardenne M. Growth hormone and insulin-like growth factor-I stimulate hormonal function and proliferation of thymic epithelial cells. $J$ Clin Endocrinol Metab 1992; 75: 183-188.

43 Rashmi M, Strong DD, Baylink DJ, Mohan S. Stimulation of human bone cell proliferation by an antisense oligodeoxyribonucleotide to IGFBP-4 mRNA. J Bone Min Res 1992; 7 (Suppl): 5124.

44 Pintar JE, Schuller A, Bradshaw S, Cerro J. Genetic analysis of IGFBP function. Proceedings of the Fourth International Symposium on IGFs Tokyo 1997; S3-2.

45 Li YM, Arkins S, McCusker RH Jr, Donovan SM, Liu Q, Jayaraman S, Dantzer R, Kelley KW. Macrophages synthesize and secrete a 25-kilodalton protein that binds insulin-like growth factor-I. J Immunol 1996; 156: 64-72.

46 Cross RJ, Eliott LH, Morford LA, Roszman TL, McGillis. Functional characterization of the insulin-like growh factor I receptor on Jurkat T cells. Cell Immunol 1995; 160: 205-210.

47 Goxe B, Martens H, Vandersmissen E, Achour I, Kecha O, Geenen V. Interactions entre les cellules $\mathrm{T}$ et la famille insulinique: étude du récepteur de l'IGF-II. Ann Endocrinol 1995; 56: 399.

48 Geenen V, Lefèbvre PJ. The intratymic expression of insulin-related genes: implication for pathophysiology and prevention of type 1 diabetes. Diabetes Metab Rev 1998; 14: 95-103. 